\title{
Putting the world on a better diet: A review of Global Eating Disorder
}

\author{
Grace Gershuny* \\ Green Mountain College
}

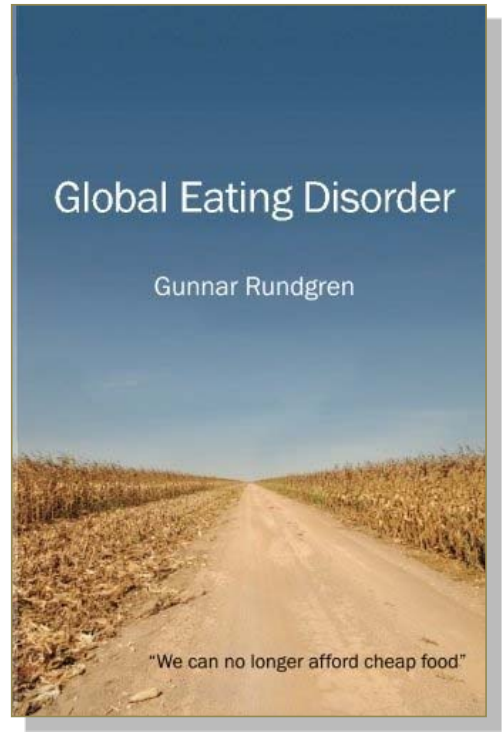

Review of Global Eating Disorder, by Gunnar Rundgren. (2014). Published by Regeneration, Uppsala, Sweden; 400 pages; available as hardcover, paperback, and Kindle.

Submitted February 2, 2016 / Published online June 6, 2016

Citation: Gershuny, G. (2016). Putting the world on a better diet: A review of Global

Eating Disorder [Book review]. Journal of Agriculture, Food Systems, and Community

Development, 6(3), 167-169. http://dx.doi.org/10.5304/jafscd.2016.063.005

Copyright (C) 2016 by New Leaf Associates, Inc.

G unnar Rundgren has written a comprehensive analysis of the current state of the global food system, how it got that way, and what it will take to move toward a more regenerative and equitable one-or, more to the point, toward diverse, locally appropriate systems. Global Eating Disorder takes the reader through a metaphorical

* Grace Gershuny, Faculty, MS in Sustainable Food Systems, Green Mountain College; 1417 Joe's Brook Road; St. Johnsbury, Vermont 05819 USA; +1-802-633-4152; gracegershuny@gmail.com

Grace Gershuny is an author and consultant, and has written extensively on soil, compost, and food system issues. As a staff member of USDA's National Organic Program in the 1990s she helped develop the organic regulations. Her latest book is Organic Revolutionary: A Memoir of the Movement for Real Food, Planetary Healing, and Human Liberation. menu that encompasses the ecological and economic dimensions of each course, and serves up the associated historical, political, and cultural considerations with relish. Prodigiously researched facts support Rundgren's arguments at every step. It all adds up to the conclusion that the way most food in today's globalized and industrial food system is produced, manufactured, transported, and marketed is creating poor health among the humans who consume it as well as the planetary ecosystems that sustain us all.

The author has a deep background as a leading international advocate, consultant, and practitioner of the kinds of solutions he envisions for the dessert course of this meal. Starting as a pioneer organic farmer, Rundgren helped develop Sweden's well-respected organic labeling scheme (KRAV), then later served as president of the International 
Federation of Organic Agriculture Movements (IFOAM) world board from 2000 to 2005. Since that time he has been a consultant and trainer, primarily in developing countries, and has helped draft policy documents for various UN agencies. Global Eating Disorder builds on information collected in the course of his work, as well as on ideas elaborated on in his previous book, Garden Earth: From Hunter and Gatherer to Global Capitalism and Thereafter, published in 2010.

Rundgren's "Appetizer," a brief essay that serves as the book's prologue, relates his experience as a consultant to the World Bank a few years previously. He was sent to the island of Samoa to assess its potential for commercial organic production as a means of bringing the island's farmers into the market economy, and thus, in theory, improving their standard of living. This brief story elucidates his motivation for writing this book, as well as his ideological framework. In the end, his "growing uneasiness" with the World Bank's basic objectives brings him to make a recommendation that gives him cause to suspect that "the World Bank will no longer want my services, and even less so after reading this book" (p. 8).

The book is nicely organized into bite-sized pieces, consisting of 29 short to medium chapters divided among sections identified as courses of a lavish meal. The opening chapter is more of an introduction, laying out the "Menu" for what is to come. The "Starters" section summarizes much of the historical information on the millennia-long evolution of agricultural systems discussed in Garden Earth, contextualizing technological developments within social, cultural, and economic changes. In the chapter entitled "The Making of Food into Commodities," Rundgren identifies land tenure issues as central to the systemic failures of today's food system, and the colonial imposition of the concept of land as private property as the basis for endemic farmer indebtedness. In a paragraph enumerating the obscene land speculation frenzy in the U.S. during the latter part of the $19^{\text {th }}$ century, he notes: "Private ownership is for some reason sacrosanct, even when it is founded on theft" (p. 73).

The second course, entitled "Primi," looks at five case studies of products that together make up a major share of the global food system: grains, grazing animals, sugar, fat, and chicken. Each of those chapters begins with a brief discourse on the language used to denote the respective type of foodstuff, conveying the importance of these products for a wide range of cultures throughout human history. The consequences of industrialscale methods of food production and processing on these basic forms of sustenance are hardly offset by their increased availability to masses of consumers.

The third section, "Secondi," delves more deeply into the problematic issues that together characterize the Global Eating Disorder. Troublesome issues connected to modern food production, such as animal factories, biofuels that replace food for humans, soil and water degradation, energy intensiveness and climate change, and the persistence of food insecurity and hunger, are thoughtfully treated. Rundgren also takes aim at the limitations of the organic industry, saying that "surviving within the market economy requires one to submit to the logic of the market" (p. 298). Regulations, whether through incentives like payments for ecosystem services or through rules that prohibit bad behavior, can only take us so far toward a solution.

Throughout the book, Rundgren provides exhaustive, fully referenced facts and figures to support his arguments. There is even an appendix, "The Digestive," that contains seven tables (inexplicably numbered 6 to 12), along with brief commentary by the author on each. The tables present data on major global food crops, including area planted, amount harvested, estimates of their contribution to protein and calorie intake, and figures on trade and biofuel production.

This depth of research alone makes Global Eating Disorder a valuable teaching resource. Rundgren's style is more personal and journalistic than academic, with occasional witty commentary. Notwithstanding its engaging style, the book is marred by serious copy-editing flaws. Originally written in Swedish, the English translation often suffers from clunky sentence construction as well as typos and spelling errors. The lack of an index is another obstacle to the book's usefulness. The table of contents is of little help, inasmuch as the food 
metaphors do not always clearly indicate the subject matter. These problems surely can be corrected in a subsequent edition.

Stories about farmers with whom Rundgren has worked also serve to illustrate his points. He repeatedly compares the situation of an Illinois maize (corn) farmer who has 3,200 hectares $(7,900$ acres) under cultivation with that of a woman farmer in Zambia, who also grows maize but on only half a hectare (1.2 acres). Anecdotes highlighting various cultural peculiarities that surround eating as well as farming balance out his extensive citation of data with warmth and humor. The ambitious scope of this book is at once a positive feature and a drawback. Rundgren's wide-ranging international perspective and sweeping analysis of the failures of the market-based system can leave one overwhelmed, at a loss to imagine a way out.

The final five chapters that make up the "Dessert" course of the book finally portray some of the programs and projects that point to an exit strategy from the Global Eating Disorder. Explicitly blaming the capitalist market economy for transforming everything involved in food production into commodities, Rundgren concludes that our entire economic and political system and its underlying values need to be massively restructured to move the food system toward an "ethics of care." Confessing that how this may be accomplished is beyond the scope of this book, he closes by saying, "I believe that food and farming provide an excellent starting point for any attempt to make a more just society and more just relations between humans. If we get food right, the rest will follow" (p. 352). While there may be other very good starting points for creating a more just society, the blatant injustice and ecological damage wrought by the current food system are motivating a new generation to advocate for radical food system change. 